ARTICLE

\title{
Electrochemical deposition as a universal route for fabricating single-atom catalysts
}

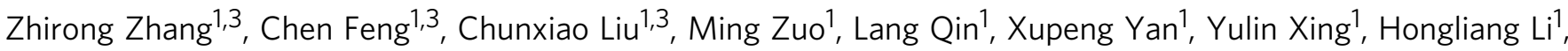 \\ Rui $\mathrm{Si}^{2}$, Shiming Zhou (iD) ${ }^{1 \times} \&$ Jie Zeng (ib) ${ }^{1 凶}$
}

Single-atom catalysts (SACs) exhibit intriguing catalytic performance owing to their maximized atom utilizations and unique electronic structures. However, the reported strategies for synthesizing SACs generally have special requirements for either the anchored metals or the supports. Herein, we report a universal approach of electrochemical deposition that is applicable to a wide range of metals and supports for the fabrication of SACs. The depositions were conducted on both cathode and anode, where the different redox reactions endowed the SACs with distinct electronic states. The SACs from cathodic deposition exhibited high activities towards hydrogen evolution reaction, while those from anodic deposition were highly active towards oxygen evolution reaction. When cathodically- and anodicallydeposited Ir single atoms on $\mathrm{Co}_{0.8} \mathrm{Fe}_{0.2} \mathrm{Se}_{2} @ \mathrm{Ni}$ foam were integrated into a two-electrode cell for overall water splitting, a voltage of $1.39 \mathrm{~V}$ was required at $10 \mathrm{~mA} \mathrm{~cm}^{-2}$ in alkaline electrolyte.

\footnotetext{
${ }^{1}$ Hefei National Laboratory for Physical Sciences at the Microscale, Key Laboratory of Strongly-Coupled Quantum Matter Physics of Chinese Academy of Sciences, Key Laboratory of Surface and Interface Chemistry and Energy Catalysis of Anhui Higher Education Institutes, Department of Chemical Physics, University of Science and Technology of China, 230026 Hefei, Anhui, People's Republic of China. ${ }^{2}$ Shanghai Synchrotron Radiation Facility, Shanghai Institute of Applied Physics, Chinese Academy of Sciences, 201204 Shanghai, People's Republic of China. ${ }^{3}$ These authors contributed equally: Zhirong Zhang, Chen Feng, Chunxiao Liu. ${ }_{\text {email: }}$ zhousm@ustc.edu.cn; zengj@ustc.edu.cn
} 
S ingle-atom catalysts (SACs), with uniform isolated metal atoms anchored on supports, have received wide interests in recent years due to their extraordinary catalytic performance towards various reactions such as water splitting, oxygen reduction, $\mathrm{CO}_{2}$ hydrogenation, and methane conversion ${ }^{1-4}$. As the supported metals are downsized to the minimum, SACs reach the utmost atom-utilization efficiency. Moreover, the atomically dispersed metal species usually exhibit unique electronic states due to distinctive coordinated environments, strong metalsupport interactions, and quantum size effects ${ }^{5-7}$. In such catalysts, the identical geometric structure of active centers also offers an ideal platform for understanding catalytic mechanisms at the atomic-scale level ${ }^{8,9}$.

SACs are not readily available since the individual metal atoms incline to diffuse and aggregate into clusters during the synthesis in order to lower surface energy. The last decade has witnessed the development of strategies for fabricating SACs. These strategies include chemical vapor deposition ${ }^{10}$, atomic layer deposition $^{11}$, pyrolysis ${ }^{12}$, wet chemistry methods ${ }^{13}$, photochemical $\operatorname{methods}^{14}$, and atom trapping ${ }^{15}$. However, these strategies usually have special requirements for either the anchored metals or the supports. For instance, the pyrolysis method generally yielded carbon-based supports because of the decomposition of metal-organic complexes ${ }^{16,17}$. Moreover, wet chemistry methods are commonly a trial-and-error process, since no consensus has been reached on the synthetic mechanism ${ }^{18,19}$. The atom trapping not only required the mobile metal species, but also demanded trapping sites on the supports ${ }^{15,20}$. Therefore, it is highly desired but challenging to develop a universal approach that is applicable to a wide range of metals and supports for the fabrication of SACs.

Here, we report electrochemical deposition as a general strategy to produce SACs. More than 30 different SACs are successfully obtained from cathodic or anodic deposition just by varying metal precursors and supports. Intriguingly, the cathodically and anodically deposited single atoms for the same metal exhibit different electronic states. Moreover, electrocatalytic tests demonstrat that these SACs obtained from cathodic deposition show a great potential for catalyzing hydrogen evolution reaction, while those from anodic deposition are promising candidates for oxygen evolution catalysts. Specially, Ir single atoms on $\mathrm{Co}_{0.8} \mathrm{~F}$ $\mathrm{e}_{0.2} \mathrm{Se}_{2}$ nanosheets from the cathodic deposition require only an overpotential of $8 \mathrm{mV}$ to reach a current density of $10 \mathrm{~mA} \mathrm{~cm}^{-2}$ for alkaline hydrogen evolution reaction. Furthermore, a twoelectrode cell assembled by cathodically and anodically deposited Ir single atoms on $\mathrm{Co}_{0.8} \mathrm{Fe}_{0.2} \mathrm{Se}_{2} @ \mathrm{Ni}$ foam exhibits a voltage of $1.39 \mathrm{~V}$ at $10 \mathrm{~mA} \mathrm{~cm}^{-2}$ for overall water splitting in alkaline electrolyte.

\section{Results}

Synthesis and characterizations of single-atom catalysts. To demonstrate the synthetic procedure, we take the deposition of Ir single atoms on $\mathrm{Co}(\mathrm{OH})_{2}$ nanosheets as an example. Specially, we used a standard three-electrode system, where $\mathrm{Co}(\mathrm{OH})_{2}$ nanosheets were loaded onto a glassy carbon electrode as the working electrode (Supplementary Fig. 1). Soluble metallic salts with a low concentration, $100 \mu \mathrm{M} \mathrm{IrCl}_{4}$ in this case, were added into the $1 \mathrm{M} \mathrm{KOH}$ electrolyte as the metal precursors. The depositing potential was set from 0.10 to $-0.40 \mathrm{~V}$ in cathodic deposition and from 1.10 to $1.80 \mathrm{~V}$ in anodic deposition for one scanning cycle, with a scanning rate of $5 \mathrm{mV} \mathrm{s}^{-1}$. The scanning cycle was repeated for ten times to obtain $\mathrm{C}-\mathrm{Ir}_{1} / \mathrm{Co}(\mathrm{OH})_{2}$ from the cathode and three times to obtain $\mathrm{A}-\mathrm{Ir}_{1} / \mathrm{Co}(\mathrm{OH})_{2}$ from the anode. Transmission electron microscopy (TEM) images and X-ray diffraction (XRD) patterns show the absence of Ir- based clusters or nanoparticles in the as-deposited samples (Supplementary Fig. 2). The energy-dispersive X-ray elemental mapping revealed that Ir species of both samples were homogeneously dispersed on the substrates (Supplementary Fig. 3). The aberration-corrected high-angle annular dark-field scanning TEM (HAADF-STEM) images of C- $\mathrm{Ir}_{1} / \mathrm{Co}(\mathrm{OH})_{2}$ and $\mathrm{A}-\mathrm{Ir}_{1} / \mathrm{Co}(\mathrm{OH})_{2}$ further demonstrated that isolated Ir atoms were uniformly distributed on the substrates (Fig. 1, a, b). The mass loadings of Ir in $\mathrm{C}-\mathrm{Ir}_{1} / \mathrm{Co}(\mathrm{OH})_{2}$ and $\mathrm{A}-\mathrm{Ir}_{1} / \mathrm{Co}(\mathrm{OH})_{2}$ were determined to be 2.0 and $1.2 \mathrm{wt} \%$, respectively, by inductively coupled plasma atomic emission spectroscopy (ICP-AES) (Supplementary Table 1).

To determine the electronic structures and coordination environment of Ir atoms in the as-deposited SACs, we performed $\mathrm{X}$-ray absorption near-edge spectroscopy (XANES) and extended $\mathrm{X}$-ray absorption fine structure (EXAFS) measurements. Figure 1c shows the Ir $L_{3}$-edge XANES spectra of $\mathrm{C}-\mathrm{Ir}_{1} / \mathrm{Co}(\mathrm{OH})_{2}$ and A- $\mathrm{Ir}_{1} / \mathrm{Co}(\mathrm{OH})_{2}$. The white line intensity for $\mathrm{C}-\mathrm{Ir}_{1} / \mathrm{Co}(\mathrm{OH})_{2}$ lay between that for $\mathrm{IrCl}_{3}$ and $\mathrm{IrO}_{2}$, indicating that the oxidation state of Ir was between +3 and +4 . By comparison, the white line intensity for $\mathrm{A}-\mathrm{Ir}_{1} / \mathrm{Co}(\mathrm{OH})_{2}$ was higher than that for $\mathrm{IrO}_{2}$, indicating a higher oxidation state of Ir than +4 . The oxidation states of Ir in both samples were also confirmed by X-ray photoelectron spectroscopy (XPS) (Supplementary Fig. 4). As shown in the EXAFS spectra of $\mathrm{C}-\mathrm{Ir}_{1} / \mathrm{Co}(\mathrm{OH})_{2}$, two peaks appeared at $1.97 \AA$ and $2.32 \AA$, which were contributed to the first coordination shell of $\mathrm{Ir}-\mathrm{O}$ and $\mathrm{Ir}-\mathrm{Cl}$, respectively (Fig. 1d). The fitting results indicated a coordination number $(C N)$ of 3.3 for Ir-O contribution and 3.1 for $\mathrm{Ir}-\mathrm{Cl}$ contribution (Supplementary Fig. 5 and Supplementary Table 2). No other typical peaks for Ir-Ir contribution at $2.71 \AA$ were observed, revealing the atomic dispersion of $\mathrm{Ir}$ atoms throughout the whole $\mathrm{C}-\mathrm{Ir}_{1} / \mathrm{Co}(\mathrm{OH})_{2}$. In the EXAFS spectra of $\mathrm{A}-\mathrm{Ir}_{1} / \mathrm{Co}(\mathrm{OH})_{2}$, only one prominent peak showed at $2.01 \AA$ for Ir-O contribution (Fig. 1d). The fitting results indicated a $C N$ of 5.8 for Ir-O contribution (Supplementary Fig. 5 and Supplementary Table 2). The absence of peaks for Ir-Ir contribution also confirmed the atomically dispersed Ir in $\mathrm{A}-\mathrm{Ir}_{1} / \mathrm{Co}(\mathrm{OH})_{2}$.

Synthetic mechanism. We propose a typical schematic for cathodic and anodic deposition of Ir species in $\mathrm{KOH}$ electrolyte according to the above results. For the cathodic deposition, iridium cations were driven towards the cathode by the applied electric field and deposited on the supports (Fig. 2a). Based on the $\mathrm{CN}$ of 3.1 for $\mathrm{Ir}-\mathrm{Cl}$ contribution, we suppose that the cations were $\mathrm{IrCl}_{3}{ }^{+}$. According to the $\mathrm{CN}$ of 3.3 for Ir-O contribution, $\mathrm{IrCl}_{3}{ }^{+}$ cations were proposed to coordinate with three $\mathrm{O}$ atoms on $\mathrm{Co}$ $(\mathrm{OH})_{2}$. Moreover, the deposition of $\mathrm{IrCl}_{3}{ }^{+}$was accompanied with a reduction of $\mathrm{Ir}$ ions under the negative electronic field, giving rise to the oxidation state of $\mathrm{Ir}$ in $\mathrm{C}-\mathrm{Ir}_{1} / \mathrm{Co}(\mathrm{OH})_{2}$ lower than +4 . For the anodic deposition, iridium anions are driven by the electric field towards the anode (Fig. 2b). The iridium anions were likely derived from the combination of $\operatorname{Ir}^{4+}$ in the precursors with $\mathrm{OH}^{-}$in the electrolyte. Ultraviolet-Visible (UV) adsorption spectrum of the $1 \mathrm{M} \mathrm{KOH}$ electrolyte containing $100 \mu \mathrm{M} \mathrm{IrCl}_{4}$ showed a prominent peak at $318 \mathrm{~cm}^{-1}$, corresponding to the adsorption of $\operatorname{Ir}(\mathrm{OH})_{6}^{2-}$ (Supplementary Fig. 6) ${ }^{21}$. This suggested that $\operatorname{Ir}(\mathrm{OH})_{6}{ }^{2-}$ anions act as the depositing species for anodic deposition, which is in accordance with the EXAFS result of $\mathrm{A}-\mathrm{Ir}_{1} / \mathrm{Co}(\mathrm{OH})_{2}$ with a $\mathrm{CN}$ of 5.8 from Ir-O contribution. Meanwhile, this anodic deposition was coupled with an oxidation process of the anions, resulting in the oxidation state of $\mathrm{Ir}$ in $\mathrm{A}-\mathrm{Ir}_{1} / \mathrm{Co}(\mathrm{OH})_{2}$ higher than +4 .

To get an insight into the deposition mechanism of SACs, we further varied the concentration of Ir precursors, the number of scanning cycles, and the scanning rate. Cathodic depositions were 
a
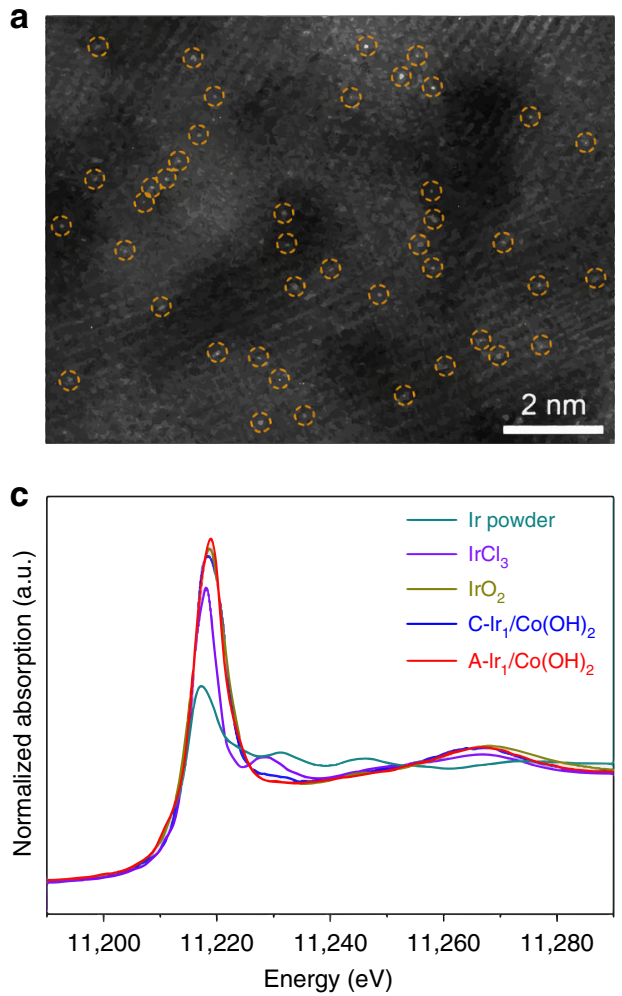

b

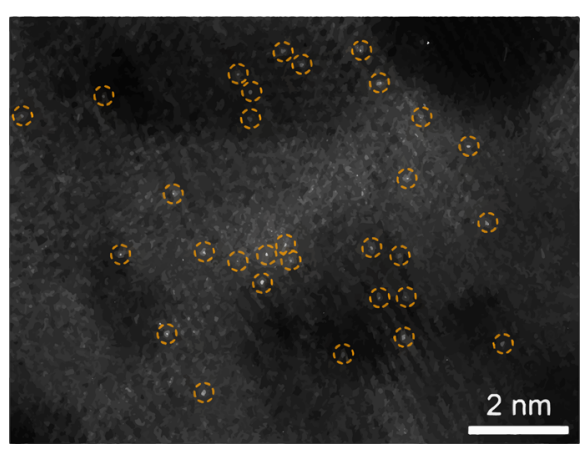

d

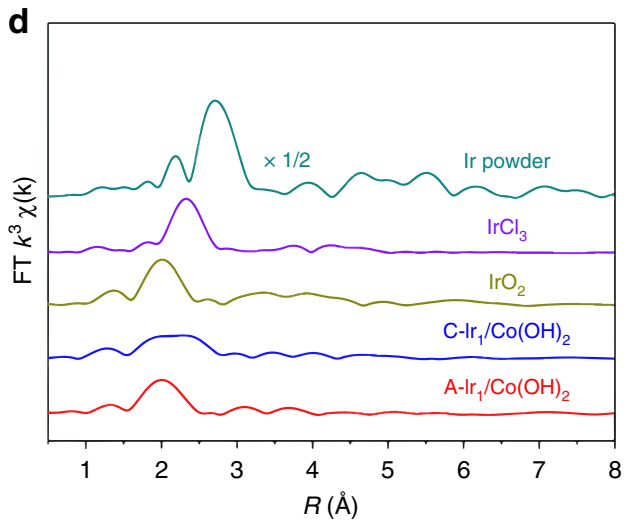

Fig. 1 Structural characterizations of Ir single atoms on $\mathbf{C o}(\mathbf{O H})_{2}$ nanosheets. a, b HAADF-STEM images of $\mathrm{C}-\mathrm{Ir}_{1} / \mathrm{Co}(\mathrm{OH})_{2}(\mathbf{a})$ and $\mathrm{A}-\mathrm{Ir} \mathrm{r}_{1} / \mathrm{Co}(\mathrm{OH})_{2}(\mathbf{b})$. Singly dispersed Ir atoms are indicated by yellow circles. c, d Normalized XANES (c) and EXAFS (d) spectra at the $\operatorname{Ir} \mathrm{L}_{3}$-edge for $\mathrm{C}-\mathrm{Ir}_{1} / \mathrm{Co}(\mathrm{OH})_{2}$ and $\mathrm{A}-\mathrm{Ir}_{1} / \mathrm{Co}(\mathrm{OH})_{2}$. Ir powder, $\mathrm{IrCl}_{3}$, and $\mathrm{IrO}_{2}$ were used as references.

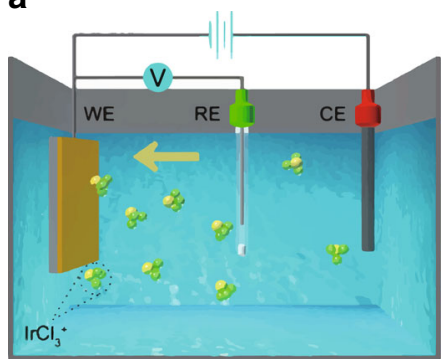

b

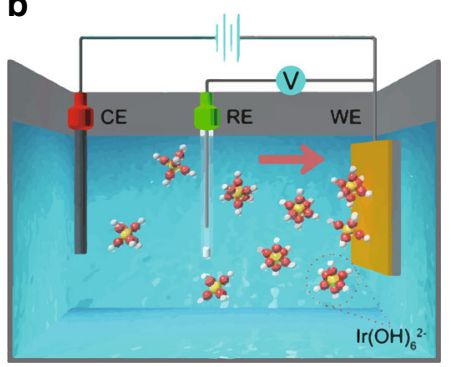

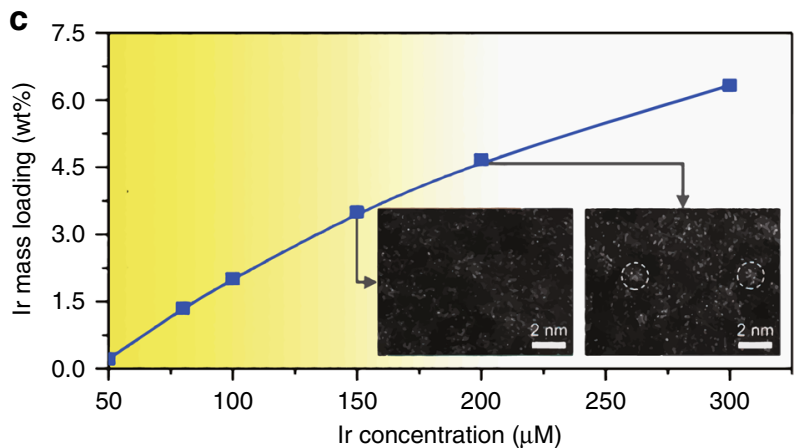

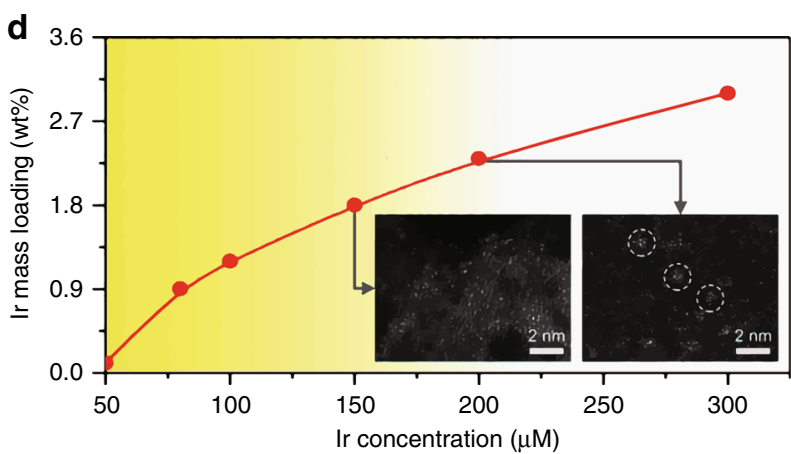

Fig. 2 Electrochemical deposition mechanism. a, b Schematic of cathodic (a) and anodic (b) deposition of Ir species. The yellow, green, red, and white spheres represent $\mathrm{Ir}, \mathrm{Cl}, \mathrm{O}$, and $\mathrm{H}$ atoms, respectively. A standard three-electrode system was used, with $\mathrm{Co}(\mathrm{OH})_{2}$ nanosheets loaded on a glassy carbon electrode as the working electrode (WE), a carbon rod as the counter electrode (CE), and an $\mathrm{Ag} / \mathrm{AgCl}$ electrode as the reference electrode (RE). c, $\mathbf{d}$ Ir mass loadings as a function of Ir concentration in the $1 \mathrm{M} \mathrm{KOH}$ electrolyte for cathodic (c) and anodic (d) deposition. The scanning cycle number was kept at ten for cathodic deposition and three for anodic deposition. The color gradient from yellow to white indicates the transition from single atoms to clusters with increasing Ir concentration. The inset images correspond to the HAADF-STEM images of the samples obtained at a certain concentration. The areas in white circles indicate the agglomerations of single atoms to form clusters. 
a
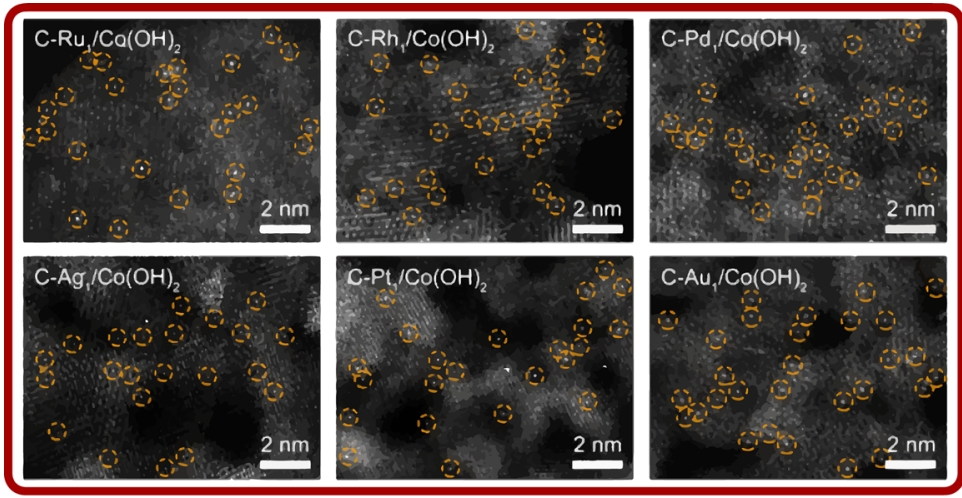

C
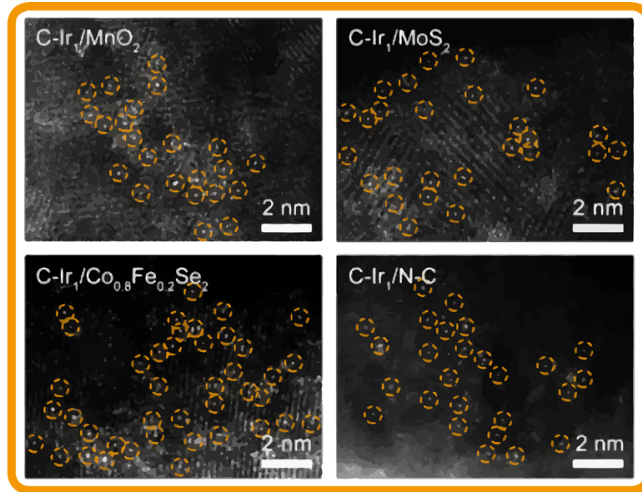

b
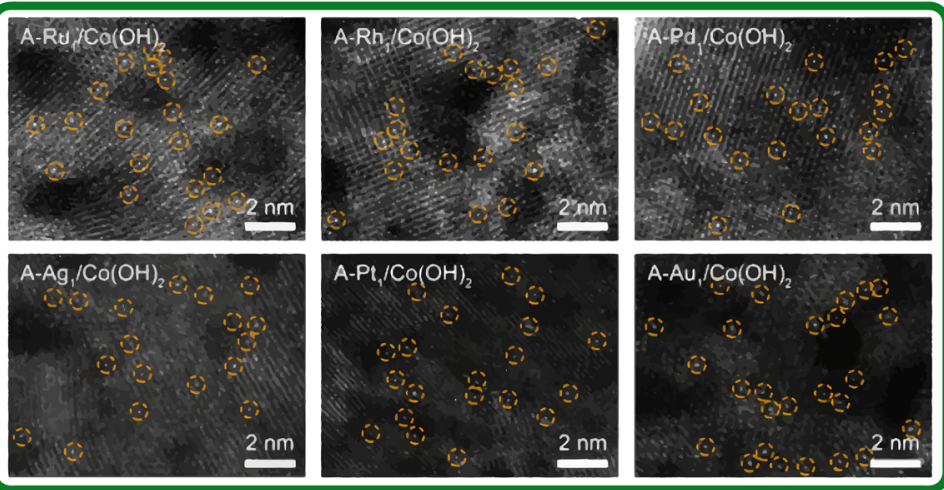

d
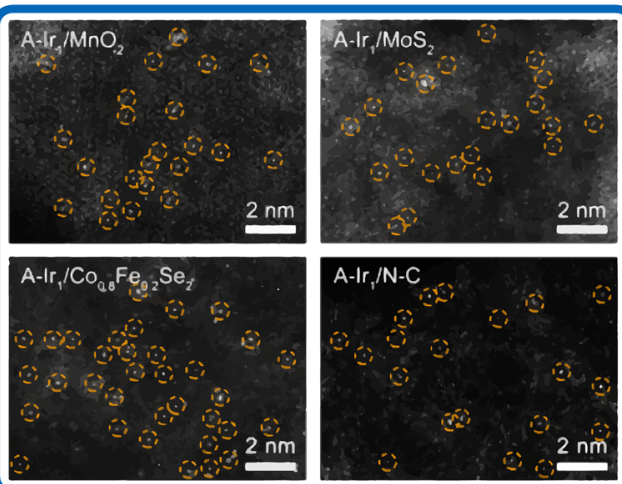

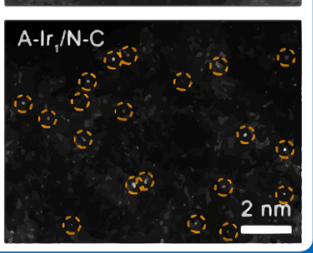

Fig. 3 Generality of electrochemical deposition for synthesizing SACs. a, b Cathodically (a) and anodically (b) deposited metal single atoms on Co(OH) nanosheets (denoted as $\mathrm{C}-\mathrm{M}_{1} / \mathrm{Co}(\mathrm{OH})_{2}$ and $\mathrm{A}-\mathrm{M}_{1} / \mathrm{Co}(\mathrm{OH})_{2}, \mathrm{M}=\mathrm{Ru}, \mathrm{Rh}, \mathrm{Pd}, \mathrm{Ag}, \mathrm{Pt}$, and $\mathrm{Au}$ ). c, d Cathodically (c) and anodically (d) deposited Ir single atoms on different supports (denoted as $\mathrm{C}-\mathrm{Ir}_{1} /$ support and $\mathrm{A}-\mathrm{Ir} /$ support, support $=\mathrm{MnO}_{2}, \mathrm{MoS}_{2}, \mathrm{Co}_{0.8} \mathrm{Fe}_{0.2} \mathrm{Se}_{2}$, and $\mathrm{N}-\mathrm{C}$ ). The depositions were all conducted in a $1 \mathrm{M} \mathrm{KOH}$ electrolyte containing $100 \mu \mathrm{M}$ metal precursors. For cathodic deposition, the deposition process was conducted in a potential range from 0.10 to $-0.40 \mathrm{~V}$ for ten scanning cycles. For anodic deposition, the deposition process was conducted in a potential range from 1.10 to $1.80 \mathrm{~V}$ for three scanning cycles. The singly dispersed metal atoms are marked by yellow circles.

conducted in $1 \mathrm{M} \mathrm{KOH}$ electrolytes via changing the $\mathrm{Ir}$ concentration from 50 to $300 \mu \mathrm{M}$ for ten scanning cycles. As shown in Fig. 2c, the mass loadings of Ir species constantly increased with the growing Ir concentration. When the Ir concentration was increased to $150 \mu \mathrm{M}$, Ir single atoms were still obtained at a mass loading of $3.5 \%$. When the concentration was further raised to $200 \mu \mathrm{M}$, Ir clusters appeared at a mass loading of $4.7 \%$. As such, for the formation of SACs, there exists an upper limit of mass loadings between $3.5 \%$ and $4.7 \%$. When we changed the scanning cycles at the Ir concentration of $100 \mu \mathrm{M}$, the upper limit of mass loadings lay between $3.3 \%$ and $3.9 \%$ for the formation of SACs (Supplementary Fig. 7a). Moreover, the Ir mass loadings increased with decreasing scanning rate, where the upper limit of mass loadings lay between $2.6 \%$ and $3.6 \%$ for the formation of SACs (Supplementary Fig. 8a). This upper limit was roughly consistent with those obtained via varying the Ir concentration and the scanning cycles. For the anodic depositions, similar phenomena were also observed, whenever the Ir concentration, the scanning cycle, and the scanning rate were changed (Fig. 2c and Supplementary Figs. $7 \mathrm{~b}$ and $8 \mathrm{~b}$ ). These electrochemical deposition processes resemble the molecular mechanism of nucleation in the solution-phase synthesis, where the support can be regarded as the solvent ${ }^{22}$. In this case, the upper limit of mass loading for SACs corresponds to the level of minimum supersaturation on the support. When the mass loadings of metal on the support exceeds the minimum supersaturation level, singly dispersed metal atoms starts to nucleate into clusters. Therefore, the formation of SACs strongly relies on controlling the mass loading below the level of minimum supersaturation. Moreover, since the isolated single atoms are usually anchored to the support through defects or strong metalsupport interaction, the value of minimum supersaturation might be relevant to the number of depositing sites such as vacancies, edges, or steps.

To test the generality of this method for synthesizing SACs, we replaced the Ir precursor with other precursors of $4 d$ and $5 d$ metals, including $\mathrm{Ru}, \mathrm{Rh}, \mathrm{Pd}, \mathrm{Ag}, \mathrm{Pt}$, and Au. HAADF-STEM images illustrated that all these metal species were successfully deposited and atomically dispersed on $\mathrm{Co}(\mathrm{OH})_{2}$ nanosheets under similar depositing conditions (Fig. 3, a, b). The atomic dispersion of metal species was further supported by in-situ diffuse reflectance infrared Fourier transform (DRIFT) experiments using $\mathrm{CO}$ as a probe molecule (Supplementary Fig. 9). Besides, the cathodic and anodic deposition of the same precursor resulted in different oxidation states of the deposited species (Supplementary Fig. 10). To further extend the applicability of this method, we utilized the same depositing method and obtained SACs comprising of other $3 d$ and $4 d$ transitional metals on nitrogen-doped carbon (N-C) support as well (Supplementary Fig. 11). We also deposited Ir single atoms onto other supports following the same procedure of synthesizing $\mathrm{Ir}_{1} / \mathrm{Co}(\mathrm{OH})_{2}$. These supports include $\mathrm{MnO}_{2}$ nanosheets, $\mathrm{MoS}_{2}$ nanosheets, $\mathrm{Co}_{0.8} \mathrm{~F}$ $\mathrm{e}_{0.2} \mathrm{Se}_{2}$ nanosheets, and N-C (Supplementary Fig. 12). Likewise, the Ir single atoms were successfully deposited on these supports 

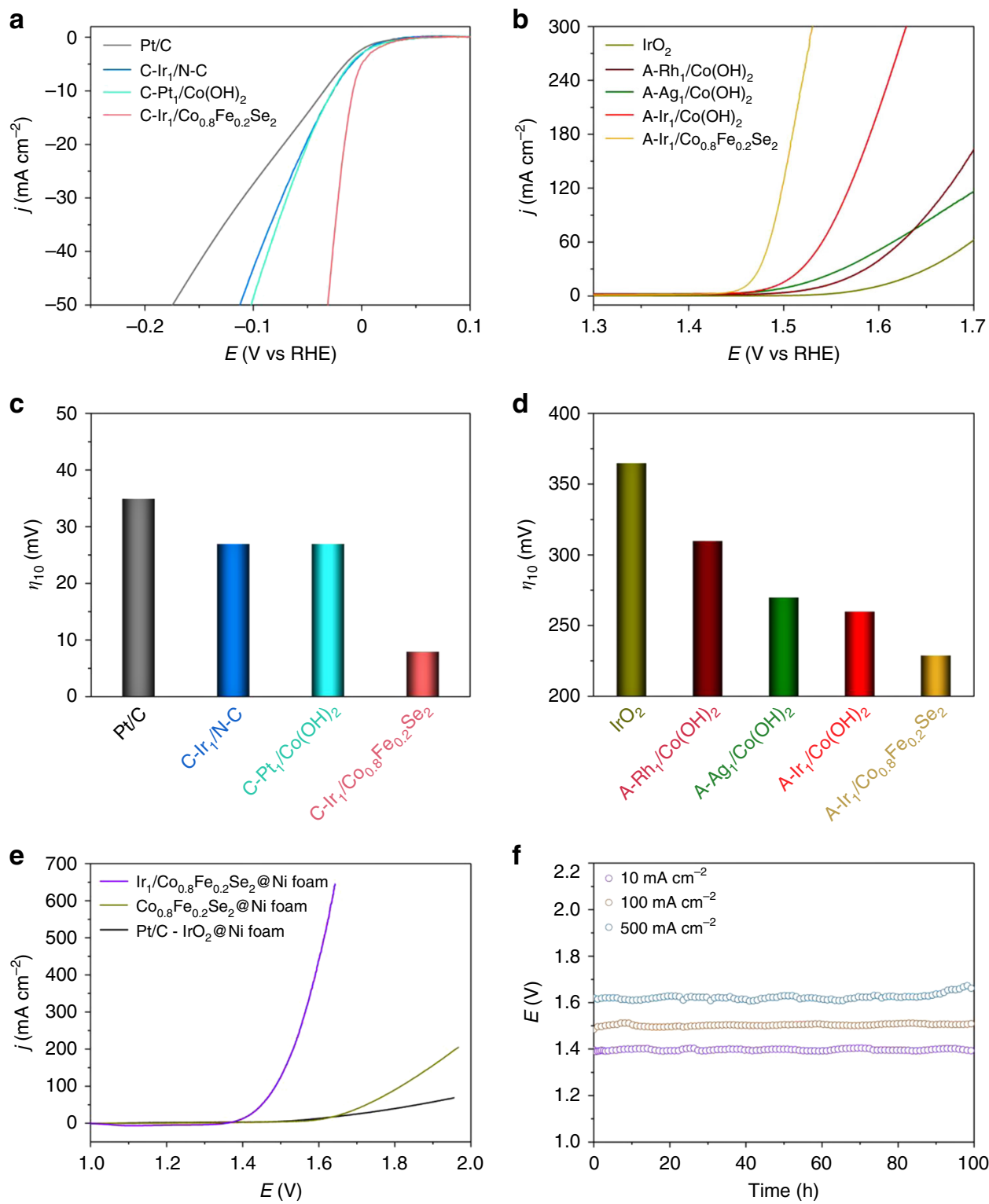

Fig. 4 Electrocatalytic performances of SACs for water splitting. a, b Polarization curves of cathodically deposited SACS for HER (a) and anodically deposited SACs for OER (b). The measurements were all conducted in $1 \mathrm{M} \mathrm{KOH}$. c, d The overpotentials at $10 \mathrm{~mA} \mathrm{~cm}^{-2}$ for HER (c) and OER (d). The commercial Pt/C and $\mathrm{IrO}_{2}$ were used as references for HER and OER, respectively. e Polarization curves of $\mathrm{Ir}_{1} / \mathrm{Co}_{0.8} \mathrm{Fe}_{0.2} \mathrm{Se}_{2} @ \mathrm{Ni}_{\text {foam for overall }}$ water splitting in the two-electrode cell. The commercial Pt/C- $-\mathrm{rO}_{2}$ coupled electrolyzer was used as a reference. $\mathbf{f}$ Chronopotentiometric curves of $\mathrm{Ir}_{1} / \mathrm{Co}_{0.8} \mathrm{Fe}_{0.2} \mathrm{Se}_{2} @ \mathrm{Ni}$ foam for overall water splitting at 10,100, and $500 \mathrm{~mA} \mathrm{~cm}{ }^{-2}$ for $100 \mathrm{~h}$.

through the cathodic or anodic deposition (Fig. 3, c, d). The absence of metal-metal bond in the EXAFS spectra further confirmed the atomic dispersion of these single atoms, in good agreement with the HAADF-STEM results (Supplementary Fig. 13). To be noted, due to the applied oxidative potential, the surface of these substrates underwent reconstructions during the anodic deposition process. The $\mathrm{Co}(\mathrm{OH})_{2}, \mathrm{MnO}_{2}, \mathrm{MoS}_{2}$, and $\mathrm{Co}_{0.8} \mathrm{Fe}_{0.2} \mathrm{Se}_{2}$ substrate was partially transferred to oxyhydroxides, amorphous phase, oxides, and oxyhydroxides, respectively, leading to vague lattice fringes in the HAADF-STEM images (Supplementary Fig. 2d and Supplementary Fig. 14). In addition, we have also applied this deposition method in acid electrolyte. Ir single atoms were successfully obtained from both cathodic and anodic deposition in $0.5 \mathrm{M} \mathrm{H}_{2} \mathrm{SO}_{4}$ (Supplementary Fig. 15). Therefore, the electrochemical deposition is a universal method that is applicable to a wide range of metals and supports for the fabrication of SACs.
Catalytic properties towards water splitting. Based on the library of obtained SACs, we searched for efficient catalysts towards water splitting, one of the most promising reactions for renewable hydrogen production. This chemical process consists of two half-reactions, including hydrogen evolution (HER) and oxygen evolution (OER) reactions ${ }^{23,24}$. The polarization curves of cathodically deposited SACs for HER and anodically deposited SACs for OER were recorded in $1 \mathrm{M} \mathrm{KOH}$ electrolyte (Fig. 4, a, b and Supplementary Fig. 16). It is worth noting that $\mathrm{C}-\mathrm{Ir}_{1} / \mathrm{N}-\mathrm{C}$, $\mathrm{C}-\mathrm{Pt}_{1} / \mathrm{Co}(\mathrm{OH})_{2}$, and $\mathrm{C}-\mathrm{Ir}_{1} / \mathrm{Co}_{0.8} \mathrm{Fe}_{0.2} \mathrm{Se}_{2}$ exhibited higher activities towards HER relative to the commercial Pt/C (Fig. 4c). Strikingly, C- $\mathrm{Ir}_{1} / \mathrm{Co}_{0.8} \mathrm{Fe}_{0.2} \mathrm{Se}_{2}$ delivered an overpotential of $8 \mathrm{mV}$ at a current density of $10 \mathrm{~mA} \mathrm{~cm}-2$, comparable to the state-ofthe-art HER catalysts in alkaline media (Supplementary Table 3). Towards OER, A- $\mathrm{Rh}_{1} / \mathrm{Co}(\mathrm{OH})_{2}, \quad \mathrm{~A}-\mathrm{Ag}_{1} / \mathrm{Co}(\mathrm{OH})_{2}, \quad \mathrm{~A}-\mathrm{Ir}_{1} / \mathrm{Co}$ $(\mathrm{OH})_{2}$, and $\mathrm{A}-\mathrm{Ir}_{1} / \mathrm{Co}_{0.8} \mathrm{Fe}_{0.2} \mathrm{Se}_{2}$, were found to be highly active compared with the benchmark $\mathrm{IrO}_{2}$. Specially, A- $\mathrm{Ir}_{1} / \mathrm{Co}_{0.8} \mathrm{Fe}_{0.2} \mathrm{Se}_{2}$ 
only needed an overpotential as low as $230 \mathrm{mV}$ to reach $10 \mathrm{~mA} \mathrm{~cm}^{-2}$, which was $135 \mathrm{mV}$ lower than that of $\mathrm{IrO}_{2}$ (Fig. 4d). The prominent HER and OER activity of Ir single atoms on $\mathrm{Co}_{0.8} \mathrm{Fe}_{0.2} \mathrm{Se}_{2}$ might originate from highly efficient charge transfer ability of the support and strong metal-support interaction (Supplementary Fig. 17) ${ }^{25-28}$.

Inspired by the high activities of as-deposited SACs towards HER and OER, we assembled C- $\mathrm{Ir}_{1} / \mathrm{Co}_{0.8} \mathrm{Fe}_{0.2} \mathrm{Se}_{2}$ and $\mathrm{A}-\mathrm{Ir}_{1} /$ $\mathrm{Co}_{0.8} \mathrm{Fe}_{0.2} \mathrm{Se}_{2}$ into a two-electrode cell for overall water splitting. The $\mathrm{Ir}_{1} / \mathrm{Co}_{0.8} \mathrm{Fe}_{0.2} \mathrm{Se}_{2}$ electrolyzer only needed a cell voltage of $1.48 \mathrm{~V}$ to reach a current density of $10 \mathrm{~mA} \mathrm{~cm}^{-2}$ and maintained the performance over $30 \mathrm{~h}$ (Supplementary Fig. 18). In order to improve the overall water splitting activity, the $\mathrm{Co}_{0.8} \mathrm{Fe}_{0.2} \mathrm{Se}_{2}$ nanosheets were further in-situ grown on $\mathrm{Ni}$ foam (denoted as $\mathrm{Co}_{0.8} \mathrm{Fe}_{0.2} \mathrm{Se}_{2} @ \mathrm{Ni}$ foam) to replace the glassy carbon electrode for more catalyst loading, higher conductivity, and better adherence of the catalysts (Supplementary Fig. 19) ${ }^{29}$. Consequently, the overpotential needed to reach $10 \mathrm{~mA} \mathrm{~cm}^{-2}$ was further decreased to $4 \mathrm{mV}$ for $\mathrm{C}-\mathrm{Ir}_{1} / \mathrm{Co}_{0.8} \mathrm{Fe}_{0.2} \mathrm{Se}_{2} @ \mathrm{Ni}$ foam during $\mathrm{HER}$, and to $140 \mathrm{mV}$ for $\mathrm{A}-\mathrm{Ir}_{1} / \mathrm{Co}_{0.8} \mathrm{Fe}_{0.2} \mathrm{Se}_{2} @ \mathrm{Ni}$ foam during OER, respectively (Supplementary Fig. 20, a, b). Afterwards, C- $\mathrm{Ir}_{1} / \mathrm{Co}_{0.8} \mathrm{Fe}_{0.2^{-}}$ $\mathrm{Se}_{2} @ \mathrm{Ni}$ foam and $\mathrm{A}-\mathrm{Ir}_{1} / \mathrm{Co}_{0.8} \mathrm{Fe}_{0.2} \mathrm{Se}_{2} @ \mathrm{Ni}$ foam were assembled into a two-electrode cell (denoted as $\mathrm{Ir}_{1} / \mathrm{Co}_{0.8} \mathrm{Fe}_{0.2} \mathrm{Se}_{2} @ \mathrm{Ni}$ foam) for overall water spiltting (Supplementary Fig. 21a). Figure $4 \mathrm{e}$ shows the polarization curves for the $\mathrm{Ir}_{1} / \mathrm{Co}_{0.8} \mathrm{Fe}_{0.2} \mathrm{Se}_{2} @ \mathrm{Ni}$ foam electrolyzer in comparison with the $\mathrm{Pt} / \mathrm{C}-\mathrm{IrO}_{2}$ coupled electrolyzer. For $\mathrm{Ir}_{1} / \mathrm{Co}_{0.8} \mathrm{Fe}_{0.2} \mathrm{Se}_{2} @ \mathrm{Ni}$ foam, only a cell voltage of $1.39 \mathrm{~V}$ was required to reach a current density of $10 \mathrm{~mA} \mathrm{~cm}^{-2}$, substantially lower than that $(1.57 \mathrm{~V})$ for the $\mathrm{Pt} / \mathrm{C}-\mathrm{IrO}_{2}$ electrolyzer (Supplementary Fig. 21b). Moreover, the Faradaic efficiency of the two-electrode cell was estimated to be $>99 \%$ towards both HER and OER, indicating that the current density only derived from water splitting (Supplementary Fig. 21, c, d). Notably, $\mathrm{Ir}_{1} / \mathrm{Co}_{0.8} \mathrm{Fe}_{0.2} \mathrm{Se}_{2} @ \mathrm{Ni}$ foam readily drove the cell to a current density as high as $500 \mathrm{~mA} \mathrm{~cm}^{-2}$ at a voltage of only $1.62 \mathrm{~V}$, which benefits for practical application in industry ${ }^{30}$. To the best of our knowledge, $\mathrm{Ir}_{1} / \mathrm{Co}_{0.8} \mathrm{Fe}_{0.2} \mathrm{Se}_{2} @ \mathrm{Ni}$ foam outperformed all the reported electrocatalysts for overall water splitting in alkaline electrolyte up to date (Supplementary Table 4). Furthermore, $\mathrm{Ir}_{1} / \mathrm{Co}_{0.8} \mathrm{Fe}_{0.2} \mathrm{Se}_{2} @ \mathrm{Ni}$ foam electrolyzer maintained its performance for over $100 \mathrm{~h}$ at a wide range of current densities in the long-term durability tests (Fig. 4f). Structural characterizations showed that $\mathrm{Ir}_{1} / \mathrm{Co}_{0.8} \mathrm{Fe}_{0.2} \mathrm{Se}_{2} @ \mathrm{Ni}$ foam showed no obvious change after the durability tests (Supplementary Fig. 22). The excellent stability of $\mathrm{Ir}_{1} / \mathrm{Co}_{0.8} \mathrm{Fe}_{0.2} \mathrm{Se}_{2} @ \mathrm{Ni}$ foam electrolyzer should be ascribed to the high stability of the $\mathrm{Co}_{0.8} \mathrm{Fe}_{0.2} \mathrm{Se}_{2} @ \mathrm{Ni}$ foam substrate (Supplementary Fig. 20, c, d) and the unique deposition strategy under the same conditions as for electrochemical measurements.

\section{Discussion}

In conclusion, we develop electrochemical deposition as a universal approach applicable to a wide range of metals and supports for the fabrication of SACs. The SACs from cathodic deposition exhibited high activities towards hydrogen evolution reaction, while those from anodic deposition were highly active towards oxygen evolution reaction. When cathodically- and anodically deposited Ir single atoms on $\mathrm{Co}_{0.8} \mathrm{Fe}_{0.2} \mathrm{Se}_{2} @ \mathrm{Ni}$ foam were integrated into a two-electrode cell for overall water splitting, a record-low voltage of $1.39 \mathrm{~V}$ was required at $10 \mathrm{~mA} \mathrm{~cm}^{-2}$ in alkaline electrolyte. The highly active and stable $\mathrm{Ir}_{1} / \mathrm{Co}_{0.8} \mathrm{Fe}_{0.2} \mathrm{Se}_{2} @ \mathrm{Ni}$ foam holds the promises for large-scale hydrogen generation. Our method to synthesize SACs provides a general route to exploit highly efficient catalysts for targeted chemical reactions.

\section{Methods}

Chemicals and materials. Iridium (IV) chloride hydrate $\left(\mathrm{IrCl}_{4} \cdot \mathrm{xH}_{2} \mathrm{O}\right)$, sodium tetrachloropalladate(II) $\left(\mathrm{Na}_{2} \mathrm{PdCl}_{4}\right)$, and gold (III) chloride hydrate $\left(\mathrm{HAuCl}_{4} \cdot \mathrm{xH}_{2} \mathrm{O}\right)$ were purchased from Aladdin. Sodium hexachlororhodate (III) dodecahydrate $\left(\mathrm{Na}_{3} \mathrm{RhCl}_{6} \cdot 12 \mathrm{H}_{2} \mathrm{O}\right)$ was purchased from Alfa Aesar. Commercial $\mathrm{Pt} / \mathrm{C}$ catalyst (20 wt\%, Pt nanoparticles with the size ranging from 2 to $5 \mathrm{~nm}$ ) was purchased from Johnson Matthey Corporation. Potassium hydroxide (KOH), sodium chloride $(\mathrm{NaCl})$, hexamethylenetetramine, 2-methylimidazole, hexaammonium heptamolybdate tetrahydrate $\left(\left(\mathrm{NH}_{4}\right)_{6} \mathrm{Mo}_{7} \mathrm{O}_{24} \cdot 4 \mathrm{H}_{2} \mathrm{O}\right)$, ethanol, methanol, thiourea, ethanolamine, sodium hydroxide $(\mathrm{NaOH})$, selenium powder (Se), hydrazine, dimethylformamide (DMF), vanadium (III) chloride $\left(\mathrm{VCl}_{3}\right)$, chromium (III) chloride $\left(\mathrm{CrCl}_{3}\right)$, manganese (II) chloride tetrahydrate $\left(\mathrm{MnCl}_{2} \cdot 4 \mathrm{H}_{2} \mathrm{O}\right)$, ferric (III) chloride $\left(\mathrm{FeCl}_{3}\right)$, cobalt (II) chloride hexahydrate $\left(\mathrm{CoCl}_{2} \cdot 6 \mathrm{H}_{2} \mathrm{O}\right)$, nickel (II) chloride $\left(\mathrm{NiCl}_{2}\right)$, copper (II) chloride $\left(\mathrm{CuCl}_{2}\right)$, zinc (II) nitrate hexahydrate $\left(\mathrm{Zn}\left(\mathrm{NO}_{3}\right)_{2} \cdot 6 \mathrm{H}_{2} \mathrm{O}\right)$, ruthenium (III) chloride $\left(\mathrm{RuCl}_{3}\right)$, silver nitrate $\left(\mathrm{AgNO}_{3}\right)$, chloroplatinic (II) acid $\left(\mathrm{H}_{2} \mathrm{PtCl}_{4}\right)$, and iridium (IV) oxide $\left(\mathrm{IrO}_{2}\right)$ were purchased from Shanghai Chemical Reagent Company. All the other chemicals were of analytical grade and used without further purification. All aqueous

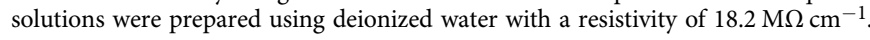

Synthesis of $\mathrm{Co}(\mathrm{OH})_{2}$ nanosheets. $\mathrm{Co}(\mathrm{OH})_{2}$ nanosheets were synthesized using a modified co-precipitation method ${ }^{31}$. In a typical procedure, $\mathrm{CoCl}_{2} \cdot 6 \mathrm{H}_{2} \mathrm{O}(2 \mathrm{mmol})$, $\mathrm{NaCl}(10 \mathrm{mmol})$, and hexamethylenetetramine $(12 \mathrm{mmol})$ were dissolved in a mixture of deionized water $(200 \mathrm{~mL})$ and ethanol $(20 \mathrm{~mL})$. The solution was magnetically stirred at $90^{\circ} \mathrm{C}$ for $2 \mathrm{~h}$, and cooled down to room temperature. The as-obtained products were washed three times with deionized water and ethanol. The final products were dried at $40^{\circ} \mathrm{C}$ under vacuum overnight.

Synthesis of $\mathbf{N}-\mathbf{C}$. The synthesis of $\mathrm{N}-\mathrm{C}$ was based on a previously reported method $^{32}$. Typically, $\mathrm{Zn}\left(\mathrm{NO}_{3}\right)_{2} \cdot 6 \mathrm{H}_{2} \mathrm{O}(1.68 \mathrm{~g})$ was dissolved in $80 \mathrm{~mL}$ of methanol. A mixture of 2-methylimidazole $(3.70 \mathrm{~g})$ and methanol $(80 \mathrm{~mL})$ was added into the above solution under vigorous stirring for $24 \mathrm{~h}$. The products were separated by centrifugation and washed three times with methanol. Then the as-obtained products were dried at $50^{\circ} \mathrm{C}$ under vacuum overnight. Afterwards, the dried powder was further activated at $200^{\circ} \mathrm{C}$ under vacuum for $24 \mathrm{~h}$. Then $500 \mathrm{mg}$ of activated powder was heated to $900^{\circ} \mathrm{C}$ with a heating rate of $5^{\circ} \mathrm{C} \mathrm{min}-1$ and carbonized at $900^{\circ} \mathrm{C}$ under $\mathrm{N}_{2}$ atmosphere for $2 \mathrm{~h}$. After naturally cooling down to room temperature, nitrogen-doped porous carbon was obtained.

Synthesis of $\mathbf{M n O}_{\mathbf{2}}$ nanosheets. In the synthesis of $\mathrm{MnO}_{2}$ nanosheets, $0.04 \mathrm{~g}$ of $\mathrm{MnCl}_{2} \cdot 4 \mathrm{H}_{2} \mathrm{O}$ was dissolved in $10 \mathrm{~mL}$ of ethanolamine under vigorous stirring at room temperature, followed by adding $10 \mathrm{~mL}$ of deionized water. Then, the mixture was stirred at room temperature for $24 \mathrm{~h}$. The obtained precipitates were washed with deionized water and ethanol. The final products were dried at $40^{\circ} \mathrm{C}$ under vacuum overnight.

Synthesis of $\mathbf{M o S}_{\mathbf{2}}$ nanosheets. $\mathrm{MoS}_{2}$ nanosheets were prepared by a reported method $^{33}$. Briefly, $\left(\mathrm{NH}_{4}\right)_{6} \mathrm{Mo}_{7} \mathrm{O}_{24} \cdot 4 \mathrm{H}_{2} \mathrm{O}(1 \mathrm{mmol})$ and thiourea $(30 \mathrm{mmol})$ were dissolved in deionized water $(35 \mathrm{~mL})$ under vigorous stirring to form a homogeneous solution. Then, the solution was transferred into a $45-\mathrm{mL}$ Teflon-lined stainless steel autoclave and maintained at $220^{\circ} \mathrm{C}$. After $18 \mathrm{~h}$, the reaction system was allowed to cool down to room temperature. The final products were washed with deionized water and ethanol for several times. The final products were dried at $40^{\circ} \mathrm{C}$ under vacuum overnight.

Synthesis of $\mathrm{Co}_{\mathbf{0 . 8}} \mathrm{Fe}_{\mathbf{0 . 2}} \mathrm{Se}_{\mathbf{2}}$ nanosheets. The synthesis of $\mathrm{Co}_{0.8} \mathrm{Fe}_{0.2} \mathrm{Se}_{2}$ nannosheets was based on the selenization of cobalt-iron hydroxides ${ }^{34}$. First, $\mathrm{CoCl}_{2} \cdot 6 \mathrm{H}_{2} \mathrm{O}(1.6 \mathrm{mmol}), \mathrm{FeCl}_{3}(0.4 \mathrm{mmol}), \mathrm{NaCl}(10 \mathrm{mmol})$, and hexamethylenetetramine $(12 \mathrm{mmol})$ were dissolved in a mixture of deionized water $(200 \mathrm{~mL})$ and ethanol $(20 \mathrm{~mL})$. The solution was magnetically stirred at $90^{\circ} \mathrm{C}$ for $2 \mathrm{~h}$, and cooled down to room temperature. The as-obtained cobalt-iron hydroxides were washed three times with deionized water and ethanol. Next, the products were dispersed in a mixture of $\mathrm{Se}(3.75 \mathrm{mmol}), \mathrm{NaOH}(7.5 \mathrm{mmol})$, hydrazine $(0.14 \mathrm{~mL})$ and DMF $(25 \mathrm{~mL})$ for selenization. The mixed solution was finally transferred into a 50 -mL autoclave. After keeping at $180^{\circ} \mathrm{C}$ for $1 \mathrm{~h}, \mathrm{Co}_{0.8} \mathrm{Fe}_{0.2} \mathrm{Se}_{2}$ nannosheets were obtained. The molar ratio of Co:Fe was determined by inductively coupled plasma atomic emission spectroscopy (ICP-AES) with a value of 0.78:0.22. The growth of $\mathrm{Co}_{0.8} \mathrm{Fe}_{0.2} \mathrm{Se}_{2}$ nanosheets on $\mathrm{Ni}$ foam followed a two-step procedure. In the first stage, cobalt-iron hydroxides were in-situ grown on Ni foam. Typically, $\mathrm{CoCl}_{2} \cdot 6 \mathrm{H}_{2} \mathrm{O}(1.6 \mathrm{mmol}), \mathrm{FeCl}_{3}(0.4 \mathrm{mmol}), \mathrm{NaCl}(10 \mathrm{mmol})$, and hexamethylenetetramine $(12 \mathrm{mmol})$ were dissolved in a mixture of deionized water $(200 \mathrm{~mL})$ and ethanol $(20 \mathrm{~mL})$. Then, acid-treated $\mathrm{Ni}$ foam $(1 \mathrm{~cm} \times 2 \mathrm{~cm})$ was added into the mixture. Next, cobalt-iron hydroxides were in-situ grown on $\mathrm{Ni}$ foam under magnetic stirring at $90^{\circ} \mathrm{C}$ for $2 \mathrm{~h}$. In the second step, the as-obtained product was further selenized. Typically, the cobalt-iron hydroxides@Ni foam was transferred into a $50-\mathrm{mL}$ autoclave containing a mixture of $\mathrm{Se}(3.75 \mathrm{mmol}), \mathrm{NaOH}(7.5 \mathrm{mmol})$, hydrazine $(0.14 \mathrm{~mL})$, and DMF $(25 \mathrm{~mL})$ for selenization. The autoclave was kept at $180^{\circ} \mathrm{C}$ for $1 \mathrm{~h}$ and then cooled down to room temperature. The final product was 
washed with ethanol for three times and dried for later use. The mass loadings of $\mathrm{Co}_{0.8} \mathrm{Fe}_{0.2} \mathrm{Se}_{2}$ nanosheets on $\mathrm{Ni}$ foam was determined to be $1 \mathrm{mg} \mathrm{cm}^{-2}$ by ICP-AES.

Synthesis of SACs. Electrochemical depositions of single-atom $M(M=I r, R u, R h$, $\mathrm{Pd}, \mathrm{Ag}, \mathrm{Pt}, \mathrm{Au}, \mathrm{Fe}, \mathrm{Co}, \mathrm{Ni}, \mathrm{Zn}, \mathrm{V}, \mathrm{Cr}, \mathrm{Mn}$, and $\mathrm{Cu}$ ) on supports were conducted using a linear sweep voltammetry method. The depositions were conducted in a standard three-electrode system. A carbon rod was used as the counter electrode. An Ag/ AgCl electrode was used as the reference electrode. The SACs were deposited on the working electrode. The as-prepared $\mathrm{Co}(\mathrm{OH})_{2}$ nanosheets, $\mathrm{MnO}_{2}$ nanosheets, $\mathrm{MoS}_{2}$ nanosheets, and $\mathrm{Co}_{0.8} \mathrm{Fe}_{0.2} \mathrm{Se}_{2}$ nanosheets supports were first mixed with equally weighted active carbon. Then the mixture was loaded onto the glassy carbon electrode by Nafion with a yield loading of $0.28 \mathrm{mg} \mathrm{cm}^{-2}$ as the working electrodes. $\mathrm{N}-\mathrm{C}$ was loaded onto the glassy carbon electrode by Nafion with a yield loading of $0.56 \mathrm{mg} \mathrm{cm}{ }^{-2}$ as the working electrode. $\mathrm{Co}_{0.8} \mathrm{Fe}_{0.2} \mathrm{Se}_{2} @ \mathrm{Ni}$ foam was directly used as the working electrode. The electrolyte contains $100 \mu \mathrm{M}$ metal precursors and $1 \mathrm{M} \mathrm{KOH}$. $\mathrm{IrCl}_{4} \cdot \mathrm{xH}_{2} \mathrm{O}, \mathrm{RuCl}_{3}, \mathrm{Na}_{3} \mathrm{RhCl}_{6} \cdot 12 \mathrm{H}_{2} \mathrm{O}, \mathrm{Na}_{2} \mathrm{PdCl}_{4}, \mathrm{AgNO}_{3}, \mathrm{H}_{2} \mathrm{PtCl}_{4}$, $\mathrm{HAuCl}_{4} \cdot \mathrm{xH}_{2} \mathrm{O}, \mathrm{FeCl}_{3}, \mathrm{CoCl}_{2} \cdot 6 \mathrm{H}_{2} \mathrm{O}, \mathrm{NiCl}_{2}, \mathrm{Zn}\left(\mathrm{NO}_{3}\right)_{2} \cdot 6 \mathrm{H}_{2} \mathrm{O}, \mathrm{VCl}_{3}, \mathrm{CrCl}_{3}$, $\mathrm{MnCl}_{2} \cdot 4 \mathrm{H}_{2} \mathrm{O}$, and $\mathrm{CuCl}_{2}$ were used as the metal precursors for $\mathrm{Ir}, \mathrm{Ru}, \mathrm{Rh}, \mathrm{Pd}, \mathrm{Ag}, \mathrm{Pt}$ $\mathrm{Au}, \mathrm{Fe}, \mathrm{Co}, \mathrm{Ni}, \mathrm{Zn}, \mathrm{V}, \mathrm{Cr}, \mathrm{Mn}$, and $\mathrm{Cu}$, respectively. The electrochemical depositions were carried out from $0.10 \mathrm{~V}$ to $-0.40 \mathrm{~V}$ for cathodic deposition and from $1.10 \mathrm{~V}$ to $1.80 \mathrm{~V}$ for anodic deposition with a sweeping rate of $5 \mathrm{mV} \mathrm{s}^{-1}$. The processes were repeated for ten times and three times in cathodic and anodic deposition, respectively. After the depositions, the electrode was washed with deionized water and directly used for later electrochemical measurements. The metal mass loadings of these asprepared SACs are shown in Table. S1. The electrochemical deposition of Ir single atoms was also carried out in acidic media using $0.5 \mathrm{M} \mathrm{H}_{2} \mathrm{SO}_{4}$ containing $100 \mu \mathrm{M}$ $\mathrm{IrCl}_{4}$ precursors as the electrolyte, and $\mathrm{N}-\mathrm{C}$ as the support.

XAFS measurements. XAFS spectra at $\operatorname{Ir} L_{3}$-edge were obtained at the BL14W1 beam line of Shanghai Synchrotron Radiation Facility operated at $3.5 \mathrm{GeV}$ under "top-up" mode with a constant current of $220 \mathrm{~mA}$. The XAFS data of $\mathrm{C}-\mathrm{Ir}_{1} / \mathrm{Co}$ $(\mathrm{OH})_{2}$ and $\mathrm{A}-\mathrm{Ir}_{1} / \mathrm{Co}(\mathrm{OH})_{2}$ were recorded under fluorescence mode with a 32 element Ge solid-state detector. The energy was calibrated according to the absorption edge of pure Ir powder. Athena and Artemis codes were used to extract the data and fit the profiles. For the XANES part, the experimental absorption coefficients as a function of energies $\mu(E)$ were processed by background subtraction and normalization procedures. We refer to this process as "normalized absorption". For the EXAFS part, the Fourier-transformed data in $R$ space were analyzed by applying the first shell approximation or metallic Ir model for the Ir-O or Ir-Ir shell, respectively. The passive electron factors, $S_{0}{ }^{2}$, were determined by fitting the experimental Ir powder data and fixing the Ir-Ir coordination number $(C N)$ to be 12. The determined factors were fixed for further analysis of the measured samples. Other parameters such as $C N$, bond distance $(R)$, and DebyeWaller $(D . W$.) factor around the absorbed atoms were allowed to vary during the fitting process. XAFS spectra of other SACs were obtained at the 1W1B beam line of Beijing Synchrotron Radiation Facility.

In-situ DRIFT. In-situ diffuse reflectance infrared Fourier transform (DRIFT) experiments of $\mathrm{CO}$ adsorption were conducted on a Fourier transform infrared spectrometer (TENSOR II Sample Compartment RT-DLaTGS). The DRIFT spectra of $\mathrm{C}-\mathrm{Rh}_{1} / \mathrm{Co}(\mathrm{OH})_{2}$ were collected with a resolution of $8 \mathrm{~cm}^{-1}$ and 64 scans in Kubelka-Munk units at $100^{\circ} \mathrm{C}$. After flowing with $\mathrm{He}(30 \mathrm{sccm})$, the background spectrum was acquired when the background was stable. Then, CO $(10 \mathrm{sccm})$ was allowed to flow into the cell until the gaseous CO peak intensity stopped growing ( $\sim 20 \mathrm{~min}$ ), suggesting saturated adsorption on the catalyst surfaces. In the end, only $\mathrm{He}(30 \mathrm{sccm})$ were used to purge out the gaseous CO from the sample cell so that the chemically adsorbed CO species on the samples could be detected. The DRIFT spectra of $\mathrm{C}-\mathrm{Pd}_{1} / \mathrm{Co}(\mathrm{OH})_{2}, \mathrm{C}_{-} \mathrm{Pt}_{1} / \mathrm{Co}(\mathrm{OH})_{2}$, and $\mathrm{C}-\mathrm{Au}_{1} / \mathrm{Co}(\mathrm{OH})_{2}$ were collected using the same procedures except for the temperature was set at $30^{\circ} \mathrm{C}$

Electrochemical measurements. An electrochemical workstation (CHI 660E, Shanghai $\mathrm{CH}$ Instruments) was used to measure the electrocatalytic properties of the samples. HER and OER electrocatalysis were measured in a standard threeelectrode system at room temperature. The glassy carbon electrode loaded with the as-obtained catalysts was used as the working electrode. A carbon rod was used as the counter electrode. An Ag/AgCl electrode was used as the reference electrode. The polarization curves were obtained using a linear sweep voltammetry method. All potentials unless specially mentioned in this work were measured against the $\mathrm{Ag} / \mathrm{AgCl}$ electrode and converted to reversible hydrogen electrode (RHE) scale by $E$ $($ vs. $\mathrm{RHE})=E($ vs. $\mathrm{Ag} / \mathrm{AgCl})+0.194 \mathrm{~V}+0.059 \mathrm{pH} \mathrm{V}$, where $0.194 \mathrm{~V}$ was obtained by calibrating the $\mathrm{Ag} / \mathrm{AgCl}$ electrode against the $\mathrm{RHE}$ in $0.5 \mathrm{M} \mathrm{H}_{2} \mathrm{SO}_{4}$. The calibration was carried out using a three-electrode system in a high-purity hydrogensaturated $0.5 \mathrm{M} \mathrm{H}_{2} \mathrm{SO}_{4}$ electrolyte using a cyclic voltammetry method with a sweep rate of $1 \mathrm{mV} \mathrm{s}^{-1}$. The $\mathrm{Ag} / \mathrm{AgCl}$ was used as the reference electrode. Pt wires were used as both the working and counter electrodes. The average of the two potentials at zero current was taken to be the thermodynamic potential for the hydrogen electrode reactions. The HER polarization curves were recorded from 0.10 to $-0.40 \mathrm{~V}$ with a sweeping rate of $5 \mathrm{mV} \mathrm{s}^{-1}$ in hydrogen-saturated $1 \mathrm{M} \mathrm{KOH}$ electrolyte. The OER polarization curves were recorded from 1.10 to $1.80 \mathrm{~V}$ with a sweeping rate of $5 \mathrm{mV} \mathrm{s}^{-1}$ in oxygen-saturated $1 \mathrm{M} \mathrm{KOH}$ electrolyte. The potentials were referred to the value $E_{i R \text {-corrected }}$ after $i R$-correction by $E_{i R \text {-corrected }}=E$ (vs RHE) $-i R$, where $i$ is the current, and $R$ is the uncompensated ohmic electrolyte resistance. In this case, $R$ was measured to be $9 \Omega$ by high-frequency alternatingcurrent impedance. Electrochemical impedance spectroscopy (EIS) for HER was conducted with alternating-current voltage with $5 \mathrm{mV}$ amplitude at the potential of $-0.20 \mathrm{~V}$ vs. RHE within the frequency range from $100 \mathrm{KHz}$ to $100 \mathrm{mHz}$. Electrochemical impedance spectroscopy (EIS) for OER was conducted with alternating-current voltage with $5 \mathrm{mV}$ amplitude at the potential of $1.53 \mathrm{~V}$ vs. RHE within the frequency range from $100 \mathrm{KHz}$ to $100 \mathrm{mHz}$. The stability tests of $\mathrm{Co}_{0.8} \mathrm{Fe}_{0.2} \mathrm{Se}_{2} @ \mathrm{Ni}$ foam towards HER and OER were conducted in a three-electrode system, where $\mathrm{Hg} / \mathrm{HgO}$ electrode was used as the reference electrode. The poten tials were converted to RHE by $E$ (vs. RHE) $=E$ (vs. $\mathrm{Hg} / \mathrm{HgO})+0.098 \mathrm{~V}+0.059$ $\mathrm{pH} \mathrm{V}$, where $0.098 \mathrm{~V}$ was obtained by calibrating the $\mathrm{Hg} / \mathrm{HgO}$ electrode against the $\mathrm{RHE}$ in $1 \mathrm{M} \mathrm{KOH}$.

Overall water splitting electrocatalysis was conducted in a two-electrode cell. $\mathrm{C}-\mathrm{Ir}_{1} / \mathrm{Co}_{0.8} \mathrm{Fe}_{0.2} \mathrm{Se}_{2} @ \mathrm{Ni}$ foam and $\mathrm{A}-\mathrm{Ir}_{1} / \mathrm{Co}_{0.8} \mathrm{Fe}_{0.2} \mathrm{Se}_{2} @ \mathrm{Ni}$ foam with an area of $1 \mathrm{~cm} \times 0.5 \mathrm{~cm}$ were used as cathode and anode, respectively. For comparison, commercial Pt/C-IrO $\mathrm{I}_{2} @ \mathrm{Ni}$ foam and $\mathrm{Co}_{0.8} \mathrm{Fe}_{0.2} \mathrm{Se}_{2} @ \mathrm{Ni}$ foam were also coupled for catalyzing overall water splitting. $\mathrm{IrO}_{2}$ was loaded on active carbon with a mass loading of $20 \%$ to form $\mathrm{IrO}_{2} / \mathrm{C}$. Both $\mathrm{Pt} / \mathrm{C}$ and $\mathrm{IrO}_{2} / \mathrm{C}$ were loaded onto $\mathrm{Ni}$ foam with a mass loading of $1 \mathrm{mg} \mathrm{cm}^{-2}$. $\mathrm{Pt} / \mathrm{C}$ on $\mathrm{Ni}$ foam was used as the cathode and $\mathrm{IrO}_{2} / \mathrm{C}$ on $\mathrm{Ni}$ foam was used as the anode. The polarization curves for overall water splitting were obtained using a linear sweep voltammetry method. The applied potential was set to range from $1.0 \mathrm{~V}$ to $2.0 \mathrm{~V}$ with a sweeping rate of $5 \mathrm{mV} \mathrm{s}^{-1}$. The potentials were corrected by $E_{i R \text {-corrected }}=E-i R$, where $R$ was measured to be $1.8 \Omega$. Durability tests were conducted in galvanostatic mode at 10,100 , and $500 \mathrm{~mA} \mathrm{~cm}{ }^{-2}$ at room temperature in $1 \mathrm{M} \mathrm{KOH}$ solution. As for the measurement of Faradaic efficiency (FE), the gaseous products were analyzed by gas chromatography. The production of $\mathrm{H}_{2}$ and $\mathrm{O}_{2}$ were measured separately in an $\mathrm{H}$-type cell containing $1 \mathrm{M} \mathrm{KOH}$ electrolyte at a current density of $10 \mathrm{~mA} \mathrm{~cm}^{-2}$ for $140 \mathrm{~min}$. In the measurement of Faradic efficiency for HER, the working electrode $\left(\mathrm{C}-\mathrm{Ir}_{1} / \mathrm{Co}_{0.8} \mathrm{Fe}_{0.2} \mathrm{Se}_{2} @ \mathrm{Ni}\right.$ foam $)$ and reference electrode $(\mathrm{Ag} / \mathrm{AgCl})$ were placed in the cathodic chamber. The counter electrode (carbon rod) was placed in the anodic chamber. During electrocatalysis, a flow of Ar at $20 \mathrm{sccm}$ was continuously sparged into the cathodic chamber as carrier gas. In the measurement of Faradic efficiency for OER, working electrode $\left(\mathrm{A}-\mathrm{Ir}_{1} / \mathrm{Co}_{0.8} \mathrm{Fe}_{0.2} \mathrm{Se}_{2} @ \mathrm{Ni}\right.$ foam) and reference electrode $(\mathrm{Ag} / \mathrm{AgCl})$ were placed in the anodic chamber. The counter electrode (carbon rod) was placed in the cathodic chamber. During electrocatalysis, a flow of Ar at $20 \mathrm{sccm}$ was continuously sparged into the anodic chamber as carrier gas.

Instrumentations. TEM images were taken on Hitachi H-7650 transmission electron microscope operating at an acceleration voltage of $100 \mathrm{kV}$. HAADF-STEM images and energy-dispersive X-ray (EDX) elemental mapping were carried out on JEOL ARM200F field-emission transmission electron microscope operating at an accelerating voltage of $200 \mathrm{kV}$ using Cu-based TEM grids. X-ray diffraction (XRD) patterns were recorded using a Philips X'Pert Pro Super diffractometer with $\mathrm{Cu}-\mathrm{Ka}$ radiation $(\lambda=$ $1.54178 \AA$ A). XPS measurements were performed on a VG ESCALAB MK II X-ray photoelectron spectrometer with $\mathrm{Mg} \mathrm{Ka}=1253.6 \mathrm{eV}$ as the exciting source. Ultraviolet-Visible (UV) adsorption spectrum was conducted on UV-Vis spectrophotometer (Agilent Technologies, Cary 60). ICP-AES (Atomscan Advantage, Thermo Jarrell Ash, USA) analyses were used to determine the mass loading of metal species. scanning electron microscope (SEM) image and energy-dispersive X-ray spectra were taken on a scanning electron microscope (SEM, JSM-6700F) operated at $65 \mathrm{kV}$. The gas products of water splitting were monitored by an online GC (SHIMADZU, GC-2014) equipped with a thermal conductivity detector and Molsieve $5 \mathrm{~A}$ colum.

\section{Data availability}

The data that support the findings of this study are available from the corresponding author on reasonable request.

Received: 22 June 2019; Accepted: 10 February 2020; Published online: 05 March 2020

\section{References}

1. Fei, H. et al. General synthesis and definitive structural identification of $\mathrm{MN}_{4} \mathrm{C}_{4}$ single-atom catalysts with tunable electrocatalytic activities. Nat. Catal. 1, 63-72 (2018).

2. Chung, H. T. et al. Direct atomic-level insight into the active sites of a high performance PGM-free ORR catalyst. Science 357, 479-484 (2017).

3. $\mathrm{Li}, \mathrm{H}$. et al. Synergetic interaction between neighbouring platinum monomers in $\mathrm{CO}_{2}$ hydrogenation. Nat. Nanotechnol. 13, 411-417 (2018).

4. Shan, J., Li, M., Allard, L. F., Lee, S. \& Flytzani-Stephanopoulos, M. Mild oxidation of methane to methanol or acetic acid on supported isolated rhodium catalysts. Nature 551, 605-620 (2017). 
5. Kwak, J. H. et al. Coordinatively unsaturated $\mathrm{Al}^{3+}$ centers as binding sites for active catalyst phases of platinum on $\gamma-\mathrm{Al}_{2} \mathrm{O}_{3}$. Science 325, 1670-1673 (2009).

6. Guo, X. et al. Direct, nonoxidative conversion of methane to ethylene, aromatics, and hydrogen. Science 344, 616-619 (2014).

7. Lin, L. et al. Low-temperature hydrogen production from water and methanol using Pt/a-MoC catalysts. Nature 544, 80-83 (2017).

8. Cui, X., Li, W., Ryabchuk, P., Junge, K. \& Beller, M. Bridging homogeneous and heterogeneous catalysis by heterogeneous single-metal-site catalysts. Nat. Catal. 1, 385-397 (2018).

9. Xu, H., Cheng, D., Cao, D. \& Zeng, X. C. A universal principle for a rational design of single-atom electrocatalysts. Nat. Catal. 1, 339-348 (2018).

10. Qiu, H. -J. et al. Nanoporous graphene with single-atom nickel dopants: an efficient and stable catalyst for electrochemical hydrogen production. Angew. Chem. Int. Ed. 54, 14031-14035 (2015).

11. Yan, H. et al. Single-atom $\mathrm{Pd}_{1} /$ graphene catalyst achieved by atomic layer deposition: remarkable performance in selective hydrogenation of 1,3butadiene. J. Am. Chem. Soc. 137, 10484-10487 (2015).

12. Yin, P. et al. Single cobalt atoms with precise $\mathrm{N}$-coordination as superior oxygen reduction reaction catalysts. Angew. Chem. Int. Ed. 55, 10800-10805 (2016)

13. Qiao, B. et al. Single-atom catalysis of $\mathrm{CO}$ oxidation using $\mathrm{Pt}_{1} / \mathrm{FeO}_{\mathrm{x}}$. Nat Chem. 3, 634-641 (2011).

14. Liu, P. et al. Photochemical route for synthesizing atomically dispersed palladium catalysts. Science 352, 797-800 (2016).

15. Jones, J. et al. Thermally stable single-atom platinum-on-ceria catalysts via atom trapping. Science 353, 150-154 (2016).

16. Yang, H. B. et al. Atomically dispersed $\mathrm{Ni}(\mathrm{I})$ as the active site for electrochemical $\mathrm{CO}_{2}$ reduction. Nat. Energy 3, 140-147 (2018).

17. Zhao, L. et al. Cascade anchoring strategy for general mass production of high-loading single-atomic metal-nitrogen catalysts. Nat. Commun. 10, 1278 (2019).

18. Nie, L. et al. Activation of surface lattice oxygen in single-atom $\mathrm{Pt} / \mathrm{CeO}_{2}$ for low-temperature CO oxidation. Science 358, 1419-1423 (2017).

19. Marcinkowski, M. D. et al. Pt/Cu single-atom alloys as coke-resistant catalysts for efficient C-H activation. Nat. Chem. 10, 325-332 (2018).

20. Qu, Y. et al. Direct transformation of bulk copper into copper single sites via emitting and trapping of atoms. Nat. Catal. 1, 781-786 (2018).

21. Zhao, Y., Vargas-Barbosa, N. M., Hernandez-Pagan, E. A. \& Mallouk, T. E. Anodic deposition of colloidal iridium oxide thin films from hexahydroxyiridate(IV) solutions. Small 7, 2087-2093 (2011).

22. LaMer, V. K. \& Dinegar, R. H. Theory, production and mechanism of formation of monodispersed hydrosols. J. Am. Chem. Soc. 72, 4847-4854 (1950).

23. Subbaraman, R. et al. Enhancing hydrogen evolution activity in water splitting by tailoring $\mathrm{Li}^{+}-\mathrm{Ni}(\mathrm{OH})_{2}-\mathrm{Pt}$ interfaces. Science 334, 1256-1260 (2011).

24. Zhang, B. et al. Homogeneously dispersed multimetal oxygen-evolving catalysts. Science 352, 333-337 (2016).

25. Jiao, Y., Zheng, Y., Davey, K. \& Qiao, S. -Z. Activity origin and catalyst design principles for electrocatalytic hydrogen evolution on heteroatom-doped graphene. Nat. Energy 1, 16130 (2016).

26. Yang, S., Tak, Y. J., Kim, J., Soon, A. \& Lee, H. Support effects in single-atom platinum catalysts for electrochemical oxygen reduction. ACS Catal. 7, 1301-1307 (2017).

27. Li, J. et al. Highly active and stable metal single-atom catalysts achieved by strong electronic metal-support interactions. J. Am. Chem. Soc. 141, 14515-14519 (2019).

28. Zhang, Y. et al. Atomic iridium incorporated in cobalt hydroxide for efficient oxygen evolution catalysis in neutral electrolyte. Adv. Mater. 30, 1707522 (2018).

29. Hui, L. et al. Multifunctional single-crystallized carbonate hydroxides as highly efficient electrocatalyst for full water splitting. Adv. Energy Mater. 8, 1800175 (2018).

30. Lu, X. \& Zhao, C. Electrodeposition of hierarchically structured threedimensional nickel-iron electrodes for efficient oxygen evolution at high current densities. Nat. Commun. 6, 6616 (2015).
31. Gao, Z. et al. Synthesis and exfoliation of layered $\alpha-\mathrm{Co}(\mathrm{OH})_{2}$ nanosheets and their electrochemical performance for supercapacitors. Eur. J. Inorg. Chem. 2013, 4832-4838 (2013)

32. Chen, Y. -Z. et al. From bimetallic metal-organic framework to porous carbon: high surface area and multicomponent active dopants for excellent electrocatalysis. Adv. Mater. 27, 5010-5016 (2015).

33. Xie, J. et al. Defect-rich $\mathrm{MoS}_{2}$ ultrathin nanosheets with additional active edge sites for enhanced electrocatalytic hydrogen evolution. Adv. Mater. 25, 5807-5813 (2013)

34. Xu, X., Song, F. \& Hu, X. A nickel iron diselenide-derived efficient oxygenevolution catalyst. Nat. Commun. 7, 12324 (2016).

\section{Acknowledgements}

This work was supported by National Science Fund for Distinguished Young Scholars (21925204), NSFC (21972132, U1732149 and U19A2015), National Key Research and Development Program of China (2019YFA0405600), Key Research Program of Frontier Sciences of the CAS (QYZDB-SSW-SLH017), Major Program of Development Foundation of Hefei Center for Physical Science and Technology (2017FXZY002), Fundamental Research Funds for the Central Universities, and USTC Research Funds of the Double First-Class Initiative (YD2340002002). This work was partially carried out at the USTC Center for Micro and Nanoscale Research and Fabrication.

\section{Author contributions}

S.Z. and J.Z. designed the study. Z.Z., C.F., and C.L. prepared the catalysts. Z.Z., C.L., L.Q., X.Y., and Y.X. performed the catalytic tests. M.Z. conducted HAADF-STEM analysis. R.S. carried out XAS measurements. S.Z., C.F., H.L., and J.Z. wrote the paper All authors discussed the results and contributed to the manuscript.

\section{Competing interests}

The authors declare no competing interests.

\section{Additional information}

Supplementary information is available for this paper at https://doi.org/10.1038/s41467020-14917-6.

Correspondence and requests for materials should be addressed to S.Z. or J.Z.

Peer review information Nature Communications thanks Elod Gyenge and other, anonymous, reviewer(s) for their contributions to the peer review of this work.

Reprints and permission information is available at http://www.nature.com/reprints

Publisher's note Springer Nature remains neutral with regard to jurisdictional claims in published maps and institutional affiliations.

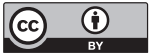

Open Access This article is licensed under a Creative Commons Attribution 4.0 International License, which permits use, sharing, adaptation, distribution and reproduction in any medium or format, as long as you give appropriate credit to the original author(s) and the source, provide a link to the Creative Commons licence, and indicate if changes were made. The images or other third party material in this article are included in the article's Creative Commons licence, unless indicated otherwise in a credit line to the material. If material is not included in the article's Creative Commons licence and your intended use is not permitted by statutory regulation or exceeds the permitted use, you will need to obtain permission directly from the copyright holder. To view a copy of this licence, visit http://creativecommons.org/ licenses/by/4.0/.

(c) The Author(s) 2020 